\title{
molecules
}

ISSN 1420-3049

www.mdpi.com/journal/molecules

Review

\section{Lectins from Edible Mushrooms}

Senjam Sunil Singh ${ }^{1}$, Hexiang Wang ${ }^{2}$, Yau Sang Chan ${ }^{3}$, Wenliang Pan ${ }^{3}$, Xiuli Dan ${ }^{3}$, Cui Ming Yin ${ }^{3}$, Ouafae Akkouh ${ }^{4}$ and Tzi Bun Ng ${ }^{3, *}$

1 Laboratory of Protein Biochemistry, Biochemistry Department, Manipur University, Canchipur, Imphal 795003, India; E-Mail: sunil_senjam@rediffmail.com

2 State Key Laboratory for Agrobiotechnology and Department of Microbiology,

China Agricultural University, Beijing 100193, China; E-Mail: hxwang@cau.edu.cn

3 School of Biomedical Sciences, Faculty of Medicine, The Chinese University of Hong Kong, Shatin, Hong Kong, China; E-Mails: bomberharo@yahoo.com.hk (Y.S.C.); wenliangpan@yahoo.com (W.P.); danxiuli@hotmail.com (X.D.); ycm1907@gmail.com (C.M.Y.)

4 Department of Biology and Medical Laboratory Research, Leiden University of Applied Science, Zernikedreef 11, Leiden 2333 CK, The Netherlands; E-Mail: ouafae@live.nl

* Author to whom correspondence should be addressed; E-Mail: b021770@mailserv.cuhk.edu.hk; Tel.: +852-3943-6872; Fax: +852-6053-5123.

Academic Editor: Derek J. McPhee

Received: 6 November 2014 / Accepted: 23 December 2014 / Published: 31 December 2014

\begin{abstract}
Mushrooms are famous for their nutritional and medicinal values and also for the diversity of bioactive compounds they contain including lectins. The present review is an attempt to summarize and discuss data available on molecular weights, structures, biological properties, N-terminal sequences and possible applications of lectins from edible mushrooms. It further aims to update and discuss/examine the recent advancements in the study of these lectins regarding their structures, functions, and exploitable properties. A detailed tabling of all the available data for N-terminal sequences of these lectins is also presented here.
\end{abstract}

Keywords: lectins; edible mushroom; medicinal value; biological properties; N-terminal sequences 


\section{Introduction}

Many species of wild mushrooms are appreciated as delicious food. They have also found a commendable place in the traditional medicines used in South-East Asian countries [1-3]. Edible mushrooms are the fleshy and edible fruit bodies of several species of macrofungi, which bear fruiting structures that are large enough to be seen with the naked eye. They can appear either below ground or above ground where they may be picked by hand. Edibility may be defined by criteria that include absence of poisonous effects on humans and having a desirable taste and aroma [4].

Mushrooms have been consumed by humans since ancient times, not only as a part of the normal diet but also as a delicacy (having desirable taste and aroma). In addition, the nutritional, tonic, and medicinal properties of mushrooms have been recognized for a long time. Mushrooms contain relatively large amounts of carbohydrate and fiber. Moreover, they also have a comparatively high level of protein (19\%-35\%, including all the essential amino acids) and are low in fat [5]. Recently, edible mushrooms have become increasingly attractive as functional foods for their potential benefit to human health [6].

Mushrooms are also known to possess a large number of nutritional, medicinal and pharmacologically important bioactive compounds including ribosome inactivating proteins, proteases, antifungal proteins, and lectins [6]. The lectins present in the mushrooms have become the subject matter of a number of studies [7,8]. So far, many mushroom lectins have been reported, and in the last few years they have attracted increased attention due to their exploitable properties encompassing a wide range of biological activities such as antiproliferative and antitumor activities toward tumor cells, hypotensive activity, immunomodulatory activity, inhibitory activity toward HIV-1 reverse transcriptase, and mitogenic activity toward spleen cells etc. [7-11].

These activities of lectins are largely attributed to the lectin-carbohydrate interactions occurring in many aspects of cellular physiology such as cell adhesion, growth and morphogenesis, molecular recognition and pathogenesis etc. Lectins generally interact with glycoproteins, glycolipids, and polysaccharides found on cell surfaces $[10,12]$. Lectins from mushrooms have also found their applications in many of the biological sciences such as in taxonomical studies, embryological and bacteriological studies, membrane glycoconjugates and cancer research, cell sorting, sorting of mutant and tumor cells and isolation of membrane and serum glyconjugates etc. [13].

The first study on mushroom lectins was reported in the year 1910 during toxicological investigations on Amanita muscaria (Fly agaric), where the lectin activity was associated with the toxicity of the mushroom. Later on, lectins from the edible mushrooms Boletus edulis (1912) and Lactarius deliciosus (1991) were reported [14]. There are many reports on lectins which were also isolated from poisonous mushrooms but their exact physiological role is still not known in detail [10]. Of these reports, mention can be made of lectins from Chlorophyllum molybdites [15], Amanita phalloides [16], Amanita pantherina [16], and Inocybe umbrinella [17], etc.

Mushrooms have become a major attraction for many investigators because of their exploitable biochemical constituents. It is important that these mushrooms are scientifically and thoroughly studied so that the potential use of the lectins based on their biological activities is justly tapped into. At the same time, there are lots of poisonous as well as edible mushrooms which are yet to be studied properly [18]. Recently, Singh et al. published an extensive review on mushroom lectins, in which 336 mushroom lectins were reported [14]. By comparing the list with edible mushrooms reported in the publication of 
E. Boa (2004) on wild edible fungi [19], we have identified about 144 lectins from edible mushrooms, 38 lectins from reported poisonous mushrooms, and 30 lectins from mushrooms which can be used as medicine and/or as food. Along with this, we try to highlight the available data from the literature pertaining to the structures, binding specificities and biological functions of lectins from the edible mushrooms (Table 1). These are the basic considerations which prompted us to prepare the present paper which is intended to be a review on lectins from edible mushrooms and the present status with a more updated summary of full or N-terminal amino acid sequences.

\section{Isolation of Lectins from Edible Mushrooms}

Lectins are generally carbohydrate-binding proteins found in a variety of organisms, including animals, plants, fungi, bacteria and viruses [20]. Pemberton conducted a lectin assay on more than 400 mushroom species and found that $50 \%$ of them contained lectins and many of them belonged to edible mushrooms [21]. These edible mushrooms have captured increasing attention due to their food and pharmaceutical values and also because of their bioactive components. So far, a large number of bioactive constituents have been isolated from edible mushrooms including small-molecular-weight compounds, polysaccharides, polysaccharide-protein complexes, proteins, etc. All these substances have interesting biological activities, such as ribosome inactivating, antimicrobial, antitumor, antioxidant, and immunomodulatory activities [22]. People started to work on edible mushroom lectins by isolating and studying their various biological activities, like those from Tricholoma mongolicum [23], Tricholoma mongolicum [24], Volvariella volvacea [25], Pleurotus ostreatus [26], Agrocybe cylindracea [27], Agrocybe aegerita [8,28], and Pleurotus citrinopileatus [20] etc.

In general, lectins from edible mushrooms are purified by using traditional purification protocols involving salt precipitation, ion-exchange chromatography, FPLC and then gel filtration steps, and sometimes along with affinity chromatography. In most of the cases, lectins from edible mushrooms were isolated from their fruiting bodies and characterized. However, there are a few reports which describe lectins from the mycelia e.g., Tricholoma mongolicum, Ganoderma lucidum, Grifola frondosa lectins $[23,29,30]$. Instances in which more than one lectin with entirely different properties were isolated from a single mushroom have also been reported [23,24,29]. 
Table 1. Structural and biological aspects of various reported lectins from edible mushrooms.

\begin{tabular}{|c|c|c|c|c|}
\hline Mushroom Species & Structural Properties & Sugar Specificity & Biological Properties & References \\
\hline Agaricus arvensis & 30.4-kDa, Homodimeric & Inulin & Antiproliferative effects against HepG2 and MCF7 tumor cells. & Zhao [31] \\
\hline Agaricus bisporus (ABL) & --- & $\begin{array}{l}\text { Gal } 1,3 \text { GalNAc (TF antigen) and Sialyl } \\
\text { Gal } 1,3 \text { GalNAc }\end{array}$ & $\begin{array}{l}\text { Antiproliferative effects on a range of cell types, can be useful for } \\
\text { modulating wound healing in subconjunctival space after glaucoma } \\
\text { surgery. Inhibits cell proliferation of some ocular and cancer cell lines }\end{array}$ & $\begin{array}{l}\text { Yu [32]; } \\
\text { Batterbury [33]; } \\
\text { Cheung [34] }\end{array}$ \\
\hline Agaricus blazei & --- & BSM, asialo-BSM, fetuin, asialofetuin, GalNAc & --- & Kawagishi [35] \\
\hline Agrocybe aegerita (AAL) & $\begin{array}{l}15.8-\mathrm{kDa}(\mathrm{AAL}) \text { Homodimeric and } \\
\text { a member of the galectin family }\end{array}$ & $\begin{array}{l}\text { Lactose BSM, glycophorin A, } \kappa \text {-casein, hog gastric } \\
\text { mucin, } \beta \text {-galactosides, } N \text {-acetylglucosamine. }\end{array}$ & $\begin{array}{l}\text { Tumor-suppressing function via apoptosis-inducing activity } \\
\text { in cancer cells }\end{array}$ & $\begin{array}{l}\text { Yang [8]; Yang } \\
\text { [28]; Yang [36]; } \\
\text { Sun [37]; Zhao } \\
\text { [38]; Ren [39] }\end{array}$ \\
\hline $\begin{array}{l}\text { Agrocybe aegerita (AAL2) } \\
\text { (another novel lectin) }\end{array}$ & 43-kDa, Monomeric & Non-reducing GlcNAc residues & Induces cell apoptosis in vitro. & Jiang [40] \\
\hline Agrocybe cylindracea & $\begin{array}{l}31.5-\mathrm{kDa} \text {, Heterodimeric }(15.3-\mathrm{kDa} \\
\text { and } 16.1-\mathrm{kDa} \text { subunits) }\end{array}$ & $\begin{array}{l}\text { Trisaccharides containing NeuAc- } \alpha 2,3 \mathrm{Gal} \beta \text {-(sialic } \\
\text { acid), inulin and lactose. Also binds to simple } \\
\beta \text {-galactosides, and their derivatives }\end{array}$ & Potent mitogenic activity toward mouse splenocytes & $\begin{array}{l}\text { Wang [27]; } \\
\text { Yagi [41]; } \mathrm{Hu}[42]\end{array}$ \\
\hline Aleuria aurantia & $\begin{array}{l}\text { 72-kDa, Homodimeric } \\
\text { Non-glycosylated, composed of two } \\
\text { identical 312-amino acid subunits }\end{array}$ & L-Fucose and fucosyl oligosaccharides & $\begin{array}{l}\text { Able to agglutinate all types of human blood erythrocytes when treated } \\
\text { with alpha ( } 1 \text { leads to } 2) \text {-fucosidase. }\end{array}$ & $\begin{array}{l}\text { Olausson [43]; } \\
\text { Kochibe [44] }\end{array}$ \\
\hline Armillaria luteo-virens & $\begin{array}{l}\text { 29.4-kDa, Dimeric, fairly } \\
\text { thermostable }\end{array}$ & Inulin & $\begin{array}{l}\text { Potent mitogenic activity toward splenocytes and antiproliferative } \\
\text { activity toward tumor cells }\end{array}$ & Feng [9] \\
\hline Auricularia polytricha & 23-kDa, Monomeric & $\begin{array}{l}\text { Raffinose, galactose, ovomucoid and } \beta \text {-anomers of } \\
\text { galactoside (lactose, p-nitrophenyl- } \beta \text {-D-galactoside) }\end{array}$ & Able to agglutinate only trypsinized human erythrocytes. & Yagi [45] \\
\hline Boletopsis leucomelas & 15-kDa, Monomeric & $\mathrm{N}$-acetyl-D-glucosamine & Apoptosis-inducing activity just like mistletoe lectins & Koyama [46] \\
\hline Boletus edulis (BEL) & Homodimeric, $16.3-\mathrm{kDa}$ subunits & D-Lactose, melibiose- and xylose-cospecific & $\begin{array}{l}\text { Stimulating effect on mitogenic response of mouse splenocytes and } \\
\text { able to inhibit HIV-1 reverse transcriptase enzyme in vitro. } \\
\text { Antineoplastic or antitumor properties. }\end{array}$ & $\begin{array}{l}\text { Zheng [47]; } \\
\text { Bovi [48]; } \\
\text { Bovi [49] }\end{array}$ \\
\hline Boletus subtomentosus & --- & D-Lactose & --- & Singh [14] \\
\hline Clavaria purpurea $(\mathrm{CpL})$ & 16-kDa, Monomeric & $\alpha$-galactosyl sugar chains and raffinose & $\begin{array}{l}\text { Potential interest for detection and characterization of glycoconjugates } \\
\text { containing Gal } \alpha 1-4 \mathrm{Gal} \text { and other } \alpha \text {-galactosyl sugars on the cell } \\
\text { surfaces. }\end{array}$ & Lyimo $[50]$ \\
\hline
\end{tabular}


Table 1. Cont.

\begin{tabular}{|c|c|c|c|c|}
\hline Mushroom Species & Structural Properties & Sugar Specificity & Biological Properties & References \\
\hline Clitocybe nebularis (CNL) & $15.9-\mathrm{kDa}$ & $N, N$-diacetyllactosediamine (GalNAcb1-4GlcNAc) & $\begin{array}{l}\text { Induces maturation and activation of dendritic cells via the toll-like } \\
\text { receptor } 4 \text { pathway. Also has immunomodulatory properties on } \\
\text { leukaemic T-cell lines. Insecticidal and anti-nutritional properties. }\end{array}$ & $\begin{array}{l}\text { Svajger [51]; } \\
\text { Pohleven [52]; } \\
\text { Pohleven [53] }\end{array}$ \\
\hline Coprinopsis cinerea (CGL3) & --- & $\begin{array}{l}\text { Oligomers of } \beta 1-4 \text { linked } N \text {-acetyl-glucosamines } \\
\text { (chitooligosaccharides) and GalNAc } \beta 1-4 \mathrm{GlcNAc} \\
\text { (LacdiNAc) }\end{array}$ & $\begin{array}{l}\text { Since fungal cell walls contain chitin, CGL3 might interfere with } \\
\text { fungal growth. }\end{array}$ & Walti [54] \\
\hline Coprinus atramentarius & --- & D-Lactose & --- & Singh [14] \\
\hline Cordyceps militaris (CML) & $\begin{array}{l}\text { Monomeric, } 31-\mathrm{kDa}, \mathrm{CML} \\
\text { comprised of } 27 \% \alpha \text {-helix, } 12 \% \\
\beta \text {-sheets, } 29 \% \beta \text {-turns, and } 32 \% \\
\text { random coils }\end{array}$ & Inhibited by sialoglycoproteins & CML exhibits mitogenic activity against mouse splenocytes & Jung [7] \\
\hline Flammulina velutipes & $12-\mathrm{kDa}$ & $\begin{array}{l}\beta \text {-D-Galactosyl residues, fetuin, human transferrin, } \\
\text { human glycophorin, lactoferrin }\end{array}$ & Inhibits proliferation of leukemia L1210 cells & $\begin{array}{l}\text { Yatohgo [55]; } \\
\mathrm{Ng}[56]\end{array}$ \\
\hline Fomes fomentarius & --- & $\alpha$-D-Galactosyl residues, GalNAc,raffinose & --- & Singh [14] \\
\hline Ganoderma capense & 18-kDa fairly heat stable & $\mathrm{D}(+)$-galactose and $\mathrm{D}(+)$-galactosamine & $\begin{array}{l}\text { Potent mitogenic activity toward mouse splenocytes, and } \\
\text { antiproliferative activity toward leukemia (L1210 and M1) cells and } \\
\text { hepatoma (HepG2) cells }\end{array}$ & Ngai [57] \\
\hline $\begin{array}{l}\text { Ganoderma lucidum (GLL-M } \\
\text { and GLL-F) }\end{array}$ & GLL-M:18-kDa, GLL-F:12-kDa & $\begin{array}{l}\text { M-glycoproteins (asialomucin and -fetuin). } \\
\text { F- glucosamine and galactosamine along with } \\
\text { glycoproteins (asialomucin, fetuin) }\end{array}$ & With health-promoting and therapeutic effects & Kawagishi [29] \\
\hline $\begin{array}{l}\text { Ganoderma lucidum (another } \\
\text { novel lectin from fruiting } \\
\text { bodies) }\end{array}$ & $\begin{array}{l}\text { 114-kDa, hexameric lectin, lysine } \\
\text { and tryptophan seem to be involved } \\
\text { in sugar binding property of lectin }\end{array}$ & Glycoproteins with $N$-as well as $O$-linked glycans & --- & Thakur $[10,12]$ \\
\hline Grifola frondosa $(\mathrm{GFL})$ & $\begin{array}{l}\text { 68-kDa, Homodimeric, high content } \\
\text { of acidic and hydroxyl amino acids } \\
\text { and low content of methionine and } \\
\text { histidine }\end{array}$ & $\begin{array}{l}\text { Terminal } N \text {-acetylgalactosamine-specific lectin, } \\
\text { porcine stomach mucin, linear D-rhamnan }\end{array}$ & Cytotoxic against HeLa cells & $\begin{array}{l}\text { Stepanova [30]; } \\
\text { Kawagishi [58] }\end{array}$ \\
\hline Gymnopilus spectabilis & $\begin{array}{l}52.1-\mathrm{kDa} \text { and } 64.4-\mathrm{kDa} \text { subunits } \\
\text { Glycoprotein }\end{array}$ & $\begin{array}{l}\text { Glycoproteins: fetuin, lactoferrin, } \\
\text { and recombinant erythropoietin }\end{array}$ & $\begin{array}{l}\text { Inhibits in vitro the growth of Staphylococcus aureus and } \\
\text { Aspergillus niger. }\end{array}$ & Alborés [59] \\
\hline
\end{tabular}


Table 1. Cont.

\begin{tabular}{|c|c|c|c|c|}
\hline Mushroom Species & Structural Properties & Sugar Specificity & Biological Properties & References \\
\hline Hericium erinaceum & $\begin{array}{l}54-\mathrm{kDa} \text {, Heterodimeric with } 15-\mathrm{kDa} \\
\text { and } 16-\mathrm{kDa} \text { subunits }\end{array}$ & Sialic acids, especially $N$-glycolylneuraminic acid & Used in Chinese medicine. & Kawagishi [60] \\
\hline Hygrophorus russula (HRL) & $\begin{array}{l}\text { 18.5-kDa Subunits } \\
\text { (Homotetrameric) }\end{array}$ & $\alpha 1-6$ mannobiose isomaltose, Glc $\alpha 1-6 \mathrm{Glc}$ & $\begin{array}{l}\text { Shows mitogenic activity against spleen lymph cells (F344 rat) and } \\
\text { strong binding of to HIV-1 gp120. }\end{array}$ & Suzuki [61] \\
\hline Kuehneromyces mutabilis & --- & $\begin{array}{l}\text { Asialo-PSM, asialofetuin, fetuin, } \alpha 1 \text { acid } \\
\text { glycoprotein, ovomucoid }\end{array}$ & --- & Singh [14] \\
\hline $\begin{array}{l}\text { Laccaria amethystine (two } \\
\text { lectins LALa and LALb) }\end{array}$ & $\begin{array}{l}\text { LALa-17.5-kDa, Monomeric } \\
\text { LALb-16-kDa, Monomeric }\end{array}$ & LALa-Lactose LALb-L-Fucose & --- & Guillot [62] \\
\hline Laccaria amethystine (LAG) & 17-kDa, Monomeric & Lactose and $N$-acetyllactosamine. & --- & Lyimo [63] \\
\hline Laccaria bicolor & --- & O-methylated mannose (and fucose) & Role in fungal defense against bacteria and nematodes & Wohlschlager [64] \\
\hline Laccaria laccata & --- & L-Fucose & --- & Singh [14] \\
\hline Lactarius deliciosus (LDL) & Dimeric, 37-kDa subunits & $\begin{array}{l}\text { Specific for D-Gal } \beta \text { 1-3D-GalNAc residues } \\
\text { (TF antigen) }\end{array}$ & $\begin{array}{l}\text { Might play a role in the mechanism of recognition between a tree and } \\
\text { its symbiont (fungus) }\end{array}$ & Guillot [65] \\
\hline Lactarius deterrimus (related) & $\begin{array}{l}\text { 37-kDa, Homodimeric } \\
\text { Non-glycoprotein }\end{array}$ & $\begin{array}{l}\text { Specific for [ } \beta] \text {-D-galactosyl(1-3)-D- } N \text {-acetyl } \\
\text { galactosamine residues (TF antigen) }\end{array}$ & $\begin{array}{l}\text { Might play a role in recognition and specificity during the early } \\
\text { stages of formation of mycorrhizae }\end{array}$ & Giollant [66] \\
\hline Lactarius flavidulus & 29.8-kDa, Dimeric & $\begin{array}{l}\text { lactose, p-nitrophenyl } \alpha \text {-D-glucopyranoside, } \\
\text { p-nitrophenyl } \beta \text {-D-glucopyranoside and inositol, } \\
\text { and by the polysaccharide inulin }\end{array}$ & $\begin{array}{l}\text { Suppresses the proliferation of hepatoma (HepG2) and leukemic } \\
\text { (L1210) cells. Inhibits the activity of HIV-1RT enzyme. }\end{array}$ & $\mathrm{Wu}[67]$ \\
\hline Lactarius lignyotus & --- & $\begin{array}{l}\text { Asialofetuin, asialo-PSM and other desialyzed } \\
\text { glycoproteins }\end{array}$ & --- & Singh $[14]$ \\
\hline Lactarius rufus & 98-kDa (containing six subunits) & $\begin{array}{l}\alpha \text {-Phenyl- } N \text {-acetyl-D-glucosaminopyranoside, } \\
\text { 4-nitrophenyl- } \beta \text {-D-Glucosamine, asialo-BSM, } \\
\text { Human and bovine thyroglobulin }\end{array}$ & $\begin{array}{l}\text { The lectin agglutinates human etrythrocytes without any marked } \\
\text { group specificity. }\end{array}$ & Panchak [68] \\
\hline Lactarius salmonicolor & --- & D-Gal- $\beta 1,3-\mathrm{D}-\mathrm{GalNAc}$ (TF antigen) & --- & Singh [14] \\
\hline Lactarius vellereus & --- & GalNAc & --- & Singh [14] \\
\hline Laetiporus sulfureus & $\begin{array}{l}\text { 35-kDa, Hexameric } \\
\text { Non-glycoprotein }\end{array}$ & Lactose $N$-acetyllactosamine & $\begin{array}{l}\text { Hemolytic property by pore forming towards blood cells. } \\
\text { Homologous to bacterial toxins. }\end{array}$ & $\begin{array}{l}\text { Konska [69]; } \\
\text { Mancheño [70]; } \\
\text { Tateno [71] }\end{array}$ \\
\hline
\end{tabular}


Table 1. Cont.

\begin{tabular}{|c|c|c|c|c|}
\hline Mushroom Species & Structural Properties & Sugar Specificity & Biological Properties & References \\
\hline Lentinus edodes & 43-kDa, Monomeric & $\begin{array}{l}\text { Mannose, D-Melibiose, Galactosyl and } \\
\text { glucosyl residues, } N \text {-acetylgalactosamine and } \\
N \text {-acetylglucosamine }\end{array}$ & Mitogenic towards murine splenic lymphocytes. & $\begin{array}{l}\text { Wang [72]; } \\
\text { Moon [73] }\end{array}$ \\
\hline Lyophyllum decastes & 10-kDa, Homodimeric & $\begin{array}{l}\text { Gal } \alpha 1,4 \mathrm{Gal} ; \alpha \text {-Galactosyl residues at the } \\
\text { nonreducing terminal }\end{array}$ & $\begin{array}{l}\text { The lectin shares carbohydrate binding preference with verocytoxin } \\
\text { of bacteria Shigella dysenteriae and E. coli } 0157: \mathrm{H} 7\end{array}$ & Goldstein [74] \\
\hline Lyophyllum shimeiji & $30-\mathrm{kDa}$ & Not inhibited by simple sugars and glycoproteins. & --- & $\mathrm{Ng}$ [75] \\
\hline Macrolepiota procera & 16-kDa Monomeric & $N$-acetyllactosamine and other $\beta$-galactosides & $\begin{array}{l}\text { Has toxic effects towards the nematode indicating a protecting role } \\
\text { against predators and parasites }\end{array}$ & Žurga [76] \\
\hline Marasmius oreades & $\begin{array}{l}\text { Consists of an intact (33-kDa) } \\
\text { and truncated ( } 23-\mathrm{kDa}) \text { subunit in } \\
\text { addition to a small polypeptide } \\
(10-\mathrm{kDa})\end{array}$ & $\begin{array}{l}\text { Gal } 1,3 \mathrm{Gal} \beta 1,4 \mathrm{GlcNAc} \text { trisaccharide sequence; } \\
\text { Blood group B trisaccharide (Gal } \alpha 1,3 \mathrm{Gal} 2,1 \alpha \mathrm{Fuc})\end{array}$ & $\begin{array}{l}\text { Human blood group B-specific lectin. Has proteolytic activity and } \\
\text { inhibits protein and DNA synthesis in NIH/3T3 cells. May induce } \\
\text { BAX-mediated apoptosis. }\end{array}$ & $\begin{array}{l}\text { Winter [77]; } \\
\text { Cordara [78]; } \\
\text { Cordara [79] }\end{array}$ \\
\hline $\begin{array}{l}\text { Marasmius oreades (MOL) } \\
\text { (another novel lectin) }\end{array}$ & $13-\mathrm{kDa}$ & Mannose and thyroglobulin & --- & Shimokawa [80] \\
\hline Mycoleptodonoides aitchisonii & 64-kDa subunit, Homotetrameric & Asialo-BSM, BSM & --- & Kawagishi [81] \\
\hline Panus conchatus & --- & D-Galactose & --- & Singh [14] \\
\hline Paxillus involutus & --- & $\begin{array}{l}\text { Asialo-PSM, Asialofetuin, Fetuin, } \\
\alpha 1 \text { acid glycoprotein }\end{array}$ & --- & Singh [14] \\
\hline Pholiota adiposa & 32-kDa, Homodimeric & Inulin & $\begin{array}{l}\text { Antiproliferative activity toward hepatoma Hep G2 cells and breast } \\
\text { cancer MCF } 7 \text { cells. It also exhibits HIV-1 reverse transcriptase } \\
\text { inhibitory activity. }\end{array}$ & Zhang [82] \\
\hline Pholiota aurivella & --- & Fetuin and Asialofetuin & --- & Singh [14] \\
\hline Pholiota squarrosa (PhoSL) & $4.5-\mathrm{kDa}$ & L-Fucose $\alpha 1$-6-fucosylated $N$-glycans. & $\begin{array}{l}\text { Able to differentiate between primary and metastatic colon cancer } \\
\text { tissues in the expression of } \alpha 1-6 \text { fucosylation. }\end{array}$ & $\begin{array}{l}\text { Singh [14]; } \\
\text { Kobayashi [83] }\end{array}$ \\
\hline Pleurocybella porrigens & 56-kDa, Homotetrameric & GalNAc and O-linked glycans & --- & Suzuki [84] \\
\hline Pleurotus citrinopileatus & 32.4-kDa subunits, Homodimeric & $\begin{array}{l}\text { Maltose, } O \text {-nitrophenyl- } \beta \text {-D-galactopyranoside, } \\
O / P \text {-nitrophenyl- } \beta \text {-D-glucuronide and inulin }\end{array}$ & $\begin{array}{l}\text { Potent antitumor, mitogenic and HIV-1 reverse transcriptase } \\
\text { inhibitory activities }\end{array}$ & $\operatorname{Li}[20]$ \\
\hline
\end{tabular}


Table 1. Cont.

\begin{tabular}{|c|c|c|c|c|}
\hline Mushroom Species & Structural Properties & Sugar Specificity & Biological Properties & References \\
\hline Pleurotus ferulae & 35-kDa, Homodimeric & D-glucose, lactose, D-galactose, and galactosamine & $\begin{array}{l}\text { Highly potent hemagglutinating and proliferative activities toward } \\
\text { mouse splenocytes }\end{array}$ & $\mathrm{Xu}[85]$ \\
\hline Pleurotus ostreatus. & $\begin{array}{l}\text { 40- and } 41-\mathrm{kDa} \text { subunits, } \\
\text { Heterodimeric }\end{array}$ & $\begin{array}{l}\text { Melibiose, lactose, D-galactose, } \\
\text { a-methyl-D-galactopyranoside, } \\
N \text {-acetylneuraminic acid, raffinose, } \\
\text { and inulin. Melibiose is the most potent inhibitory } \\
\text { sugar }\end{array}$ & $\begin{array}{l}\text { Potent antitumor activity in sarcoma S-180 bearing and hepatoma } \\
\text { H-22 bearing mice. Enhances immunogenicity of some vaccines in } \\
\text { transgenic mice. Possesses anti-inflammatory activities }\end{array}$ & $\begin{array}{l}\text { Wang [26]; } \\
\text { Gao [86]; } \\
\text { Jedinak [87] }\end{array}$ \\
\hline Pleurotus tuber-regium & $32-\mathrm{kDa}$ & $N$-acetylglucosamine-binding & $\begin{array}{l}\text { Exhibits hemagglutinating activity toward trypsinized rabbit } \\
\text { erythrocytes but not toward untrypsinized rabbit erythrocytes. }\end{array}$ & Wang [88] \\
\hline Polyporus adusta & 12-kDa subunits, Homodimeric & Turanose is the most potent inhibitory sugar & $\begin{array}{l}\text { Antiproliferative activity toward tumor cell lines and mitogenic } \\
\text { activity toward splenocytes }\end{array}$ & Wang [89] \\
\hline Polyporus squamosus & 28-kDa subunits, Homodimeric & NeuNAc $\alpha 2,6 \beta$ galactosyl residues & $\begin{array}{l}\text { Can be a valuable tool for glycobiological studies in biomedical and } \\
\text { cancer research }\end{array}$ & Mo [90] \\
\hline Psathyrella velutina & $\begin{array}{l}\text { 40-kDa, Monomeric having a regular } \\
\text { seven-bladed } \beta \text {-propeller fold }\end{array}$ & $\begin{array}{l}N \text {-acetylglucosamine and } \\
N \text {-acetylneuraminic acid specific }\end{array}$ & Used in detection of glycosylation abnormality in rheumatoid IgG & $\begin{array}{l}\text { Cioci [91]; } \\
\text { Kochibe [92] }\end{array}$ \\
\hline Russula delica & 60-kDa, Homodimeric & Inulin and $O$-nitrophenyl-beta-D-galactopyranoside & $\begin{array}{l}\text { Potent inhibitor for proliferation of HepG2 hepatoma and } \\
\text { MCF } 7 \text { breast cancer cells, also inhibits HIV-1 reverse } \\
\text { transcriptase activity. }\end{array}$ & Zhao [93] \\
\hline Russula lepida (RLL) & 16-kDa subunits, Homodimeric & Inulin and $O$-nitrophenyl-b-D-galacto-pyranoside & $\begin{array}{l}\text { Antiproliferative activity towards hepatoma Hep G2 cells and } \\
\text { human breast cancer MCF- } 7 \text { cells }\end{array}$ & Zhang [11] \\
\hline Russula nigricans & --- & $\begin{array}{l}\text { Asialofetuin, asialo-PSM, Fetuin, Ovomucoid, } \\
\text { a1 Acid glycoprotein }\end{array}$ & --- & Singh [14] \\
\hline Schizophyllum commune & 64-kDa, Homodimeric & Lactose-specific & $\begin{array}{l}\text { Potent mitogenic activity toward mouse splenocytes, antiproliferative } \\
\text { activity toward tumor cell lines, and inhibitory activity toward HIV-1 } \\
\text { reverse transcriptase }\end{array}$ & Han [94] \\
\hline $\begin{array}{l}\text { Stropharia rugosoannulata } \\
\text { (SRL) }\end{array}$ & 38-kDa, Homodimeric & Inulin & $\begin{array}{l}\text { Exhibits anti-proliferative activity toward both hepatoma Hep G2, } \\
\text { cells and leukemia L1210 cells, along with anti HIV-1 reverse } \\
\text { transcriptase activity. }\end{array}$ & Zhang [95] \\
\hline
\end{tabular}


Table 1. Cont

\begin{tabular}{|c|c|c|c|c|}
\hline Mushroom Species & Structural Properties & Sugar Specificity & Biological Properties & References \\
\hline $\begin{array}{l}\text { Tricholoma mongolicum } \\
\text { TML-1 and TML-2* }\end{array}$ & $\begin{array}{l}\text { 37-kDa, Homodimeric, } \\
\text { non-glycoprotein in nature }\end{array}$ & Lactose & $\begin{array}{l}\text { Exhibits antiproliferative activities against mouse } \\
\text { monocyte-macrophage PU5-1.8 cells and mouse mastocytoma P } 815 \\
\text { cells in vitro. Stimulates production of nitrite ions by macrophages in } \\
\text { normal and tumor-bearing mice. }\end{array}$ & $\begin{array}{l}\text { Wang [23]; } \\
\text { Wang [24] }\end{array}$ \\
\hline Volvariella volvacea $(\mathrm{VVL})$ & $\begin{array}{l}\text { 32-kDa, Homodimeric, } \\
\text { Non- glycoprotein }\end{array}$ & $\begin{array}{l}\text { Inhibited not by simple sugars } \\
\text { but by thyroglobulin }\end{array}$ & $\begin{array}{l}\text { Potent stimulatory activity towards murine splenic lymphocytes } \\
\text { showing immuno-modulatory activity. Also found to enhance } \\
\text { transcriptional expression of interleukin- } 2 \text { and interferon- } \gamma\end{array}$ & She [25] \\
\hline Xerocomus chrysenteron & $15-\mathrm{kDa}$ & $\begin{array}{l}\text { Asialofetuin, asialo-PSM and other desialyzed } \\
\text { glycoproteins GalNAc and Gal TF antigen }\end{array}$ & $\begin{array}{l}\text { It possesses a high insecticidal activity against the dipteran } \\
\text { Drosophila melanogaster and the hemipteran, Acyrthosiphon pisum. }\end{array}$ & Trigueros [96] \\
\hline Xerocomus spadiceus & $\begin{array}{l}\text { 32.2-kDa (16-kDa subunits), } \\
\text { Dimeric }\end{array}$ & Inulin-specific & $\begin{array}{l}\text { Capable of eliciting an approximately four-fold stimulation of } \\
\text { mitogenic response in murine splenocytes }\end{array}$ & Liu [97] \\
\hline Xylaria hypoxylon & 28.8-kDa, Homodimeric & Inulin- and xylose- specific & $\begin{array}{l}\text { Potent hemagglutinating activity, antiproliferative activity towards } \\
\text { tumor cell lines, and anti-mitogenic activity on mouse splenocytes }\end{array}$ & Liu [98] \\
\hline
\end{tabular}

--- Data not available from the authors; * These two lectins differ in the amino acid composition (proline and tyrosine residues) and TML-2 possesses a higher hemagglutinating activity than TML-1, whereas TML-1 has a more potent antiproliferative activity against PU5-1.8 cells than TML-2, especially in the presence of serum.

TML-1 possesses hypotensive and vasorelaxing action in rats [99]. 


\section{Structural Properties and Sugar Specificities of Edible Mushroom Lectins}

In general, lectins possess many shallow binding pockets/cassettes that are hydrophilic and the interaction with carbohydrates and lectins are typically weak. In order to achieve strength and specificity, many lectins exist as oligomers consisting of several similar or identical monomers each of which binds to the same type of carbohydrate. In this way, lectins may participate in multivalent binding, or the formation of several simultaneous binding events that provide an apparent binding affinity (functional affinity) greater than the sum of the individual interactions $[10,12]$. To support the aforesaid statements, Yang et al., illustrated the structural basis for the apoptosis-inducing activity of an antitumor lectin from the edible mushroom Agrocybe aegerita (AAL) [36]. AAL has a dimeric organization and the authors showed that this dimerization of AAL is essential for its apoptosis-inducing activity toward tumor cells. Two sugars, glucose and galactose, are basic moieties of functional carbohydrate ligands for lectin bioactivity. They also identified another hydrophobic pocket essential for apoptosis-inducing activity of the lectin but which is independent of its carbohydrate binding and dimer formation. All these findings reveal a structural basis for the antitumor activities of AAL, which may even lead to the design of antitumor drugs based on the AAL prototype model [36].

Some mushroom lectins have been reported to be sensitive to inhibition of agglutination by more than a single sugar and/or sugar derivative, like lectins from Agrocybe cylindracea (lactose, sialic acid and inulin), Boletus edulis (melibiose- and xylose-cospecific), Ganoderma capense (D+-galactose and $\mathrm{D}^{+}$-galactosamine), Ganoderma lucidum (mycelial lectin inhibited by glycoproteins asialomucin and -fetuin; fruiting body lectin inhibited by glucosamine and galactosamine along with glycoproteins asialomucin, fetuin), Lentinus edodes ( $N$-acetylgalactosamine and $N$-acetylglucosamine), Pleurotus citrinopileatus (maltose, $O$-nitrophenyl- $\beta$-D-galactopyranoside, $O / P$-nitrophenyl- $\beta$-D-glucuronide and inulin), Pleurotus ostreatus (melibiose, lactose, D-galactose, a-methyl-D-galactopyranoside, $\mathrm{N}$-acetylneuraminic acid, raffinose, and inulin, with melibiose being the most potent), Psathyrella velutina ( $N$-acetylglucosamine and $N$-acetylneuraminic acid specific), Russula lepida (inulin and $O$-nitrophenyl- $\beta$-D-galacto-pyranoside), and Xylaria hypoxylon (inulin- and xylose- specific) etc. (Table 1). Among the different sugars one of them might be the most potent inhibitory sugar. Some edible mushroom lectins have specificity towards complex carbohydrates rather than simple sugars e.g., lectins from Volvariella volvacea, Ganoderma lucidum, and Cordyceps militaris (Table 1). There are also some lectins whose hemagglutinating activities are unaffected by simple sugars or sugar derivatives or complex glycoproteins. Examples in this category include lectins from Lyophyllum shimeiji, Agaricus edulis, Flammulina velutipes and Volvariella volvacea [75].

The molecular weights of most lectins isolated from edible mushrooms range from $12-\mathrm{kDa}$ to $68-\mathrm{kDa}$. Some lectins isolated from edible mushrooms are non-glycoproteins such as lectins from Tricholoma mongolicum [23], Laetiporus sulfueus [69], Lactarius deterrimus [66], and Volvariella volvacea [25]. Another prominent characteristic is that except for a few lectins which are either monomeric or multimeric, almost all other lectins from edible mushrooms are dimeric (Table 1). Wang et al. isolated two distinct lectins from the edible mushroom Tricholoma mongolicum, having significant biological properties [23]. These lectins (TML-1 and TML-2) have a molecular weight of 37-kDa and are non-glycoprotein in nature. The hemagglutinating activities of both lectins are sensitive to inhibition by 
lactose. However, it was reported that the amino acid compositions of these two lectins differ in the content of proline and tyrosine residues [99].

A structurally novel lectin (VVL) was isolated by She et al., [25], from the edible straw mushroom Volvariella volvacea. This lectin is homodimeric with a molecular weight of 32-kDa (non-glycoprotein), and its hemagglutination activity is inhibited not by simple sugars but by thyroglobulin. Wang et al., isolated a heterodimeric lectin (composed of $40-\mathrm{kDa}$ and $41-\mathrm{kDa}$ subunits) from fresh fruiting bodies of the edible mushroom Pleurotus ostreatus [26]. The inhibition of hemagglutination induced by this lectin is sensitive to inhibition by salts such as $\mathrm{CaCl}_{2}, \mathrm{MgCl}_{2}, \mathrm{MnCL}_{2}$ and $\mathrm{FeCl}_{3}$ and by sugars and sugar derivatives such as melibiose, lactose, D-galactose, $\alpha$-methyl-D-galactopyranoside, $N$-acetylneuraminic acid, raffinose, and inulin. Among these sugars, melibiose is the most potent [26]. A lectin having a unique N-terminal amino acid sequence (Table 2) was isolated by Li et al. from an edible mushroom Pleurotus citrinopileatus [20]. This lectin is a homodimer with a molecular weight of 32.4-kDa and likewise this lectin is not inhibited by a single sugar. Rather, it has multiple sugar specificities (maltose, $O$-nitrophenyl- $\beta$-D-galactopyranoside, $\mathrm{O} / \mathrm{P}$-nitrophenyl- $\beta$-D-glucuronide and inulin).

Table 2. N-terminal amino acid sequences of lectins from edible mushrooms.

\begin{tabular}{|c|c|c|}
\hline Mushroom Species & N-Terminal Sequences & Reference \\
\hline Agaricus arvensis & TYAVLNFVYG & Zhao [100] \\
\hline Agaricus bisporus & MGGSGTSGSL & Zhang [82]; Crenshaw [101] \\
\hline Agrocybe aegerita & QGVNIYNI & Yang [32]; Zhao [38] \\
\hline Agrocybe cylindracea (15.3-kDa subunit) & AVNFYNVLAGAENDLVADVE & Wang [27] \\
\hline Agrocybe cylindracea (16.1-kDa subunit) & RVTNVANGFVAGDQKAMVRV & Wang [27] \\
\hline Coprinopsis cinerea & IPLEGTFGDR & Walti $[50]$ \\
\hline Flammulina velutipes & TSLTFQLAYL & Zhang [82]; Ko [102] \\
\hline Ganoderma capense & VNDYEAWYGADD & Ngai [57] \\
\hline Ganoderma lucidum & QFIYNGKFNWLNYALNETIT & Thakur $[10,12]$ \\
\hline Grifola frondosa & NWPAEMMIDLKHPIVEMR & Kawagishi [58] \\
\hline Hericium erinaceum & AFGQLSFANLAAADF & $\operatorname{Li}[103]$ \\
\hline Laccaria bicolor & SHLYGDGVAL & Martin [104] \\
\hline Lyophyllum shimeiji & PVVFELKFPNNNPESLLALAACARNKAH & $\mathrm{Ng}[75]$ \\
\hline Marasmius oreades & YILDGEYLVL & Kruger [105] \\
\hline Paxillus involutus & CTCAVFLNNTTVKS & Wang [106] \\
\hline Pholiota adiposa & DILMGTYGML & Zhang [82] \\
\hline Pholiota aurivella & YSVTTPNSVKGGTNQG & Zhang [11]; Kawagishi [107] \\
\hline Pleurotus citrinopileatus & QYSQMAQVME & $\operatorname{Li}[20]$ \\
\hline Pleurotus cornucopiae & SDSTWTFAML & Oguri $[108]$ \\
\hline Pleurotus ostreatus (40-kDa subunit) & ATAKIKATPAQPQQFQPAALNAAK & Wang [26] \\
\hline Pleurotus ostreatus (41-kDa subunit) & ACATAKCTTATPQQPGCAPAALNAAK & Wang [26] \\
\hline Pleurotus tuber-regium & DRXAGYVLYXXVPY & Wang $[88]$ \\
\hline Russula lepida & VWYIVAIKTDVPRTT & Zhang [11] \\
\hline Stropharia rugosoannulata & IKSGVYRIVSWQGALGPEAR & Zhang [95] \\
\hline Volvariella volvacea & PSNGNQYLIAQAYNLQKVNFDYTPQWQRGN & She $[25]$ \\
\hline Xerocomus spadiceus & CSKGGVGRGYGIG & Liu [97] \\
\hline
\end{tabular}


In one of the structural studies on lectin from Aleuria aurantia (AAL) using two forms of recombinant AAL produced by using site-directed mutagenesis, it was revealed that this lectin is composed of two subunits with a six-fold $\beta$-propeller structure containing five binding sites for L-fucose. The interesting finding was that all five binding sites have different binding affinities for fucose. Sites 2 and 4 have the highest affinities toward fucose, while site 1 has an intermediate affinity, and sites 3 and 5 bind fucose with weaker affinities [43].

Structural characterization of Laetiporus sulphureus lectins by Mancheño et al., [70] shows that this lectin is a hexameric protein (composed of $35-\mathrm{kDa}$ subunits) while previously it was considered as tetrameric [69,71]. It has also been established to have two distinct modules: an N-terminal lectin module and a pore-forming module. The lectin module has a $\beta$-trefoil scaffold structure resembling that of the toxins abrin and ricin. While the other module exhibits three-dimensional structural similarities with that of the bacterial $\beta$-pore-forming toxin aerolysin and $\epsilon$-toxin. The crystal structure of the sugar-lectin complex reveals the presence of two sugar binding sites per subunit [70].

Žurga et al. determined the crystal structure of the dimeric Macrolepiota procera lectin $(\mathrm{MpL})$ and it was found that it has a $\beta$-trefoil scaffold structure. It has a carbohydrate-binding site at the $\alpha$-repeat which manifests the highest specificity for terminal $N$-acetyllactosamine and other $\beta$-galactosides. Another low-affinity putative carbohydrate-binding site is also present at the $\gamma$-repeat. A second putative carbohydrate-binding site with a low affinity for galactose is present at the $\gamma$-repeat. In addition, a novel hydrophobic binding site has been detected in $\mathrm{MpL}$ with specificity for molecules other than carbohydrates [76].

Nowadays, lectin microarray studies have become popular as mushroom lectins are considered potent therapeutic agents. An example is the use of a high throughput miniaturized platform of lectin microarray for the detection of terminal or interior glucose, mannose and fucose residues [109]. Such structural characterizations of proteins (edible mushroom lectins) are very useful for defining their valences, specificities, and affinities. As such, they will surely have a commendable place in developing reliable diagnostic and biological assays for carbohydrate analysis.

\section{Functional Properties of Lectins from Edible Mushrooms}

Thakur et al., reported that, compared to higher plants, the role of lectins in fungi seems to be more complicated [10,12]. For instance, in higher fungi (mushrooms), lectins play different roles in different situations. Some of these include functions in fungal metabolism, and other roles in symbiotic or parasitic relationships with other organisms. In addition, various roles such as parasitic and predatory behaviors have also been ascribed to the lectins in lower fungi [110]. $\mathrm{Ng}$ reported that mushroom lectins are localized on the caps, stipes and the mycelia [13]. These lectins may also play various crucial roles in physiological processes such as dormancy, growth, morphogenesis, morphological changes and molecular recognition during the early stages of mycorrhization [110].

Khan et al. also commented on the possible properties of mushroom lectins attributed to their biological roles in the host organism [111]. The ability of lectins to recognize different glycosylated structures at the levels of cells, tissues and the whole organisms endow these molecules with a number of physiological roles such as participation of parasitic mushrooms in the host organism e.g., by recognition between a tree and its symbiont (mushroom) [65]. They also help in recognition and 
specificity during the early stages of mycorrhizal formation, introducing morphological changes in the host and in dormancy [66]. A mechanism of how lectin plays an innate role in the host defense mechanism was also recently demonstrated by a lectin from the edible mushroom Laccaria bicolor (Lb-Tec2) [64]. Here, lectins not only act as recognition molecules for pathogens, they can also perform the direct defense effectors' function by intoxicating the antagonist upon binding.

The lectin family, particularly lectins from mushrooms, has drawn growing interest from the scientific community in the last decade due to its potential importance in cancer research. Lectins from edible mushrooms such as those of Agaricus bisporus, Boletus satanus, Flammulina velutipes, Ganoderma lucidum, Grifola frondosa, Tricholoma mongolicum, and Volvariella volvacea are reported to have immunomodulatory and/or antitumor/cytotoxic/antiproliferative activities [36,57].

In 1984, during an early part of mushroom lectin research, isolation of a heterodimeric lectin from the edible mushroom Volvariella volvacea encouraged the search for potential agents in lectins from mushrooms for cancer therapy. This lectin has a moderate inhibitory effect on the growth of tumor

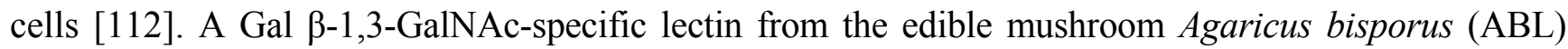
purified by $\mathrm{Yu}$ et al. has reversible noncytotoxic inhibiting effects on epithelial cell proliferation [32]. An $\mathrm{N}$-acetylgalactosamine-specific lectin (GFL) from Grifola frondosa (GFL) fruiting bodies shows cytotoxic activity against HeLa cells. However, if this lectin has been pre-incubated with haptenic sugar $\mathrm{N}$-acetylgalactosamine, it is unable to exhibit its cytotoxicity. This finding indicates that the sugar binding site plays an important role in providing it with its toxic effects [71].

Lectins isolated from the mushroom Tricholoma mongolicum (TML1 and TML2) exhibited antiproliferative activity against mouse monocyte-macrophage PU5-1.8 cells and mouse mastocytoma P815 cells in vitro. The same lectins also stimulated the production of nitrite ions by macrophages in normal and tumor-bearing mice and inhibited the growth of sarcoma 180 cells in the peritoneal cavity in mice [23,24]. Another lectin from Pleurotus ostreatus exerted potent antitumor activity in mice bearing sarcoma S-180 and hepatoma H-22 [26], while lectin from Agrocybe cylindracea exhibited potent mitogenic activity toward mouse splenocytes [27].

Koyama et al., isolated a comparatively smaller monomeric lectin (15-kDa) from another edible mushroom Kurokawa (Boletopsis leucomelas), having apoptosis-inducing activity just like that of mistletoe lectins [46]. This lectin induces all the features of apoptosis such as formation of apoptotic bodies, chromatin condensation, and DNA ladder formation [46]. Another smaller (18-kDa) but fairly heat stable $\left(0-100^{\circ} \mathrm{C}\right)$ lectin isolated by Ngai et al. from the mycelial extract of mushroom Ganoderma capense exhibits a more potent mitogenic activity toward mouse splenocytes and antiproliferative activity toward leukemia (L1210 and M1) cells and hepatoma (HepG2) cells compared to concanavalin A [57]. Yang et al., reported a member of the galectin family of lectins from the mushroom Agrocybe aegerita (AAL) and recombinant Agrocybe aegerita lectin (rAAL) having tumor cell apoptosis-inducing activity on human and mouse tumour cells $[8,113]$. Pleurotus citrinopileatus lectin is a structurally novel lectin with potent antitumor, mitogenic and HIV-1 reverse transcriptase inhibitory activities [20].

Other promising lectins include mannose-specific lectin from the mushroom Hygrophorus russula (HRL) which shows mitogenic activity towards spleen lymph cells of F344 rats and strong binding affinity for HIV-1 gp120 [61]. Lectin from Lactarius flavidulus is able to suppress the proliferation of hepatoma (HepG2) and leukemic (L1210) cells and inhibit the activity of HIV-1 RT enzyme [67]. Similarly, lectin from an edible mushroom Pholiota squarrosa (PhoSL) also demonstrates the ability to 
differentiate between primary and metastatic colon cancer tissues with regard to the expression of a1-6 fucosylation [83]. This suggests the potential application of this PhoSL as a cancer biomarker. Another novel lectin isolated from the edible mushroom Clitocybe nebularis (CNL) exhibits an immunostimulatory effect on most potent antigen-presenting cells, the dendritic cells (DCs) [51]. In the same paper, the authors have also shown that DCs activation by CNL is completely dependent on the toll-like receptor 4 (TLR4) activation pathway.

\section{N-Terminal Sequences of Lectins from Edible Mushrooms}

Generally, mushroom lectins show high diversity in the N-terminal sequences, followed by some conserved sequences $[10,12]$. In the early 90s, Kawagishi et al., determined the N-terminal amino acid sequence of Pholiota aurivella agglutinin (PAA) [58]. The amino acid sequence analysis gave no evidence of heterogeneity in the primary structure of the first $16 \mathrm{~N}$-terminal residues (YSVTTPNSVKGGTNQG) which has a high content of serine, glycine, and acidic amino acids [107].

AAL is an Agrocybe aegerita lectin with an amino acid composition rich in neutral nonpolar amino acids (glycine, alanine, valine) and acidic amino acids. This lectin also has a low content of methionine, arginine, lysine and histidine residues and traces of cysteine residues which is consistent with the low isoelectric point of AAL. The amino end of the native AAL contained pyroglutamyl and after treatment with pyroglutamate aminopeptidase, the sequence of the first eight $\mathrm{N}$-terminal amino acids of AAL was determined to be (QGVNIYNI) [37,38,113]. Zhang et al. studied the N-terminal amino-acid sequence (DILMGTYGML) of Pholiota adiposa lectin (PAL) and they found that the sequence showed little similarity to sequences of other published Agaricales mushroom lectins, such as lectins from Agaricus bisporus, Agrocybe aegerita, Coprinopsis cinerea, Flammulina velutipes, Laccaria bicolor, Marasmius oreades, Pholiota aurivella, and Pleurotus cornucopiae [82].

Thakur et al. reported comparatively longer N-terminal sequences from Ganoderma lucidum lectin which does not indicate similarity to any known lectin. The first 20 residues of the lectin have been reported as QFIYNGKFNWLNYALNETIT [10,12]. Hericium erinaceum lectin isolated by Li et al. possesses a distinctive N-terminal sequence AFGQLSFANLAAADF, with little resemblance to some of the published mushroom lectins [103]. Even more recently, Wang et al. presented N-terminal amino acid sequence of the Paxillus involutus lectin (CTCAVFLNNTTVKS), which has a low level of similarity to previously reported mushroom lectin sequences [106].

Fungal immunomodulatory proteins (FIP) are also well known for their similar bio-functional activities with that of lectins. Both types of proteins are able to agglutinate RBCs and bind to cell surface sugar moieties. There are some reports on the full amino acid sequences of such FIP and lectins from edible mushrooms [31]. To mention a few, they are Aleuria aurantia lectin, Hygrophorus russula lectin, LZ-8 and LZ-9 from Ganoderma lucidum, FIP-fve from Flammulina velutipes and FIP-gts from Ganoderma tsugae [51,61-63]. By knowing the full sequence of a protein, one can study the importance of a specific region by deletion analysis of amino acids in that domain. For example, after deletion analysis of the N-terminal amphipathic $\alpha$-helix domain of FIP-gts, Lin et al. (1997) identified that the sequence of first 10 amino acids is responsible for inducing the immunomodulatory activity and the sequence of first 13 amino acids is responsible for dimerization of this protein [114]. 
A list of N-terminal sequences of lectins from different edible mushrooms is presented in Table 2 and full amino acid sequences for some lectins and related FIP from edible mushrooms in Table 3. These represent the sequence information available about these proteins. A comparison of $\mathrm{N}$-terminal sequences reveals the differences among the various isolated lectins although it does not exclude the possibility of substantial sequence homology in the remaining part of the sequences.

Table 3. Full amino acid sequences of some lectins and related fungal immunomodulatory proteins (FIP) from edible mushrooms.

\begin{tabular}{|c|c|c|}
\hline Lectins/FIP & Complete Amino Acid Sequences & References \\
\hline Aleuria aurantia lectin & $\begin{array}{l}\text { 1-PTEFLYTSKIAAISWAATGGRQQRVYFQDLNGKIREAQRGG } \\
\text { DNPWTGGSSQNVIGEAKLFSPLAAVTWKSAQGIQIRVYCVN } \\
\text { KDNILSEFVYDGSKWITGQLGSVGVKVGSNSKLAALQWGGS } \\
\text { ESAPPNIRVYYQKSNGSGSSIHEYVWSGKWTAGASFGSDVPG } \\
\text { DGIGATAIGPGRIRIYYQATINKIREHQQDSNSWYVGGFSASA } \\
\text { SAGVSIAAISWGSTPNIRVYWQKGREELYEAAYGGSWNTPG } \\
\text { QIKDASRPTPSLPDTFIAANSSGNIDISVFFQASGVSLQQWQWI } \\
\text { SGKGWSIGAVVPTGTPAGW-312 }\end{array}$ & Fukumori [100] \\
\hline FIP-fve & $\begin{array}{l}\text { 1-MSATSLTFQLAYLVKKIDFDYTPNWGRGTPSSYIDNLTFPK } \\
\text { VLTDKKYSYRVVVNGSDLGVESNFAVTPSGGQTINFLQYNK } \\
\text { GYGVADTKTIQVFVVIPDTGNSEEYIIAEWKKT-115 }\end{array}$ & Bastiaan-Net [115] \\
\hline FIP- $g t s$ & $\begin{array}{l}\text { 1-SDTALIFRLAWDVKKLSFDYTPNWGRGNPNNFIDTVTFPK } \\
\text { VLTDKAYTYRVAVSGRNLGVKPSYAVESDGSQKVNFLEYNS } \\
\text { GYGIADTNTIQVFVVDPDTNNDFIIAQWN-110 }\end{array}$ & Lin $[114]$ \\
\hline $\begin{array}{l}\text { Hygrophorus russula } \\
\text { lectin (HRL) }\end{array}$ & $\begin{array}{l}\text { 1-TIGTAKPILAQTAIVGGPSVPFDDAREVASWPAKLEIAQDFP } \\
\text { ITGITVRHGQIINNLTIIYRTVNGNSATVSHGGDSGGIVDKVAL } \\
\text { NENEIITSVQGRAGQHRSYNRPYLDSISFTILDTKTLVTRTTNI } \\
\text { FGNGDGTNQGDPFQVAQPYAFAGATYTDGQTGVAGLSFFK } \\
\text { VITNA-175 }\end{array}$ & Suzuki [61] \\
\hline LZ-8 & $\begin{array}{l}\text { 1-MSDTALIPRLAWDVKKLSFDYPTNWGRGNPNNFIDTVTFP } \\
\text { KVLTDKAYTYRVAVSGRNLGVKPSYAVESDGSQKVNFLEY } \\
\text { NSGYGIADTNTIQVFVVDPDTNNDFIIAQWN-111 }\end{array}$ & Bastiaan-Net [115] \\
\hline LZ-9 & $\begin{array}{l}\text { 1-MSDTALIPRLAWEIKKLAFDYPTNWGRGNPSSYIDTVTFPQ } \\
\text { VLTGKEYTYRVAVSGKDLGVRPSYAVESDGSQKVNFLEYNA } \\
\text { GYGIADKNTIQVYVIDPDTGNDFIIAQWN-111 }\end{array}$ & Bastiaan-Net [115] \\
\hline
\end{tabular}

\section{Conclusions}

Edible mushrooms are not only known for their flavors and culinary features. Evidence has been accumulating that mushrooms have nutritional as well as medicinal value. They have also been universally acknowledged as valuable sources of biologically important compounds having many potential applications in health sciences [116]. Other than polysaccharides, mushrooms produce a large number of pharmacologically active proteins, including fungal immunomodulatory proteins (FIP), ribosome inactivating proteins (RIP), antibacterial/antifungal proteins, lectins, ribonucleases, laccases and other proteins $[3,116]$. They are indeed good sources of novel lectins with unique specificity and potential for biomedical and biotechnological applications. Among the various lectins reported in the 
literature, lectins from edible mushrooms still have a juvenile status in terms of their structural and functional characterization. There are reports on lectins from edible mushrooms and their applications based on immunomodulating, antiproliferative, and antiviral/antimicrobial activities. It is also obvious that there is a need for further studies on the structural characterization of these lectins in terms of amino acid sequences, X-ray crystallography studies, and proteomics, as well as to explore various aspects to elucidate their structure-function relationships.

More information on $\mathrm{N}$-terminal sequences and genomic analyses on these lectins would be helpful in appraising these important biomolecules. Hence, many food-producing industries and pharmaceutical companies need to focus on cultivating and harboring lectins from wild edible mushrooms. Although there are reports on the biological properties of lectins from edible mushrooms, very few have shown how these molecules actually play their role in the host organisms. This area still remains obscure. It is hoped that these lectins from edible mushrooms can be developed into clinically useful drugs and may be useful in designing new therapeutic drugs for many human diseases.

\section{Acknowledgments}

We duly acknowledge the support of this publication by DBT, Govt. of India, under DBT's Biotechnology Overseas Associateship program.

\section{Author Contributions}

S.S.S. was responsible for writing the review and did the final editing of the manuscript. H.W. and O.A. assisted in writing the structural aspects in the review. Y.S.C. and W.P. prepared the tables. X.D. and C.M.Y. contributed by collecting information on the N-terminal amino acid sequences. T.B.N. assisted in providing references for the manuscript and edited and proofread the manuscript.

\section{Conflicts of Interest}

The authors declare no conflict of interest.

\section{References}

1. Ajith, T.A.; Janardhanan, K.K. Indian medicinal mushrooms as a source of antioxidant and antitumor agents. J. Clin. Biochem. Nutr. 2007, 40, 157-162.

2. Ng, T.B. A review of research on the protein-bound polysaccharide (polysaccharopeptide, PSP) from the mushroom Coriolus versicolor (Basidiomycetes: Polyporaceae). Gen. Pharmacol. 1998, 30, $1-4$.

3. Xu, X.; Yan, H.; Chen, J.; Zhang, X. Bioactive proteins from mushrooms. Biotechnol. Adv. 2011, 29, 667-674.

4. Chang, S.T.; Miles, P.G. Mushrooms: Cultivation, Nutritional Value, Medicinal Effect, and Environmental Impact; CRC Press: London, UK, 1989; pp. 4-6.

5. Mattila, P.; Suonpää, K.; Piironen, V. Functional properties of edible mushrooms. Nutrition 2000, 16, 694-696. 
6. Guillamón, E.; García-Lafuente, A.; Lozano, M.; D’Arrigo, M.; Rostagno, M.A.; Villares, A.; Martínez, J.A. Edible mushrooms: Role in the prevention of cardiovascular diseases. Fitoterapia 2010, 81, 715-723.

7. Jung, E.C.; Kim, K.D.; Bae, C.H.; Kim, J.C.; Kim, D.K.; Kim, H.H. A mushroom lectin from ascomycete Cordyceps militaris. Biochim. Biophys. Acta 2007, 1770, 833-838.

8. Yang, N.; Liang, Y.; Xiang, Y.; Zhang, Y.; Sun, H.; Wang, D.C. Crystallization and preliminary crystallographic studies of an antitumour lectin from the edible mushroom Agrocybe aegerita. Protein Pept. Lett. 2005, 12, 705-707.

9. $\quad$ Feng, K.; Liu, Q.H.; Ng, T.B.; Liu, H.Z.; Li, J.Q.; Chen, G.; Sheng, H.Y.; Xie, Z.L.; Wang, H.X. Isolation and characterization of a novel lectin from the mushroom Armillaria luteo-virens. Biochem. Biophys. Res. Commun. 2006, 345, 1573-1578.

10. Thakur, A.; Rana, M.; Lakhanpal, T.N.; Ahmad, A.; Khan, M.I. Purification and characterization of lectin from fruiting body of Ganoderma lucidum: Lectin from Ganoderma lucidum. Biochim. Biophys. Acta 2007, 1770, 1404-1412.

11. Zhang, G.; Sun, J.; Wang, H.; Ng, T.B. First isolation and characterization of a novel lectin with potent antitumor activity from a Russula mushroom. Phytomedicine 2010, 17, 775-781.

12. Thakur, A.; Pal, L.; Ahmad, A.; Khan, M.I. Complex Carbohydrate Specificity of Lectin from Fruiting Body of Ganoderma lucidum. A Surface Plasmon Resonance Study. IUBMB Life 2007, 59, 758-764.

13. Ng, T.B. Peptides and proteins from fungi. Peptides 2004, 25, 1055-1073.

14. Singh, R.S.; Bhari, R.; Kaur, H.P. Mushroom lectins: Current status and future perspectives. Crit. Rev. Biotechnol. 2010, 30, 99-126.

15. Kobayashi, Y.; Kobayashi, K.; Umehara, K.; Dohra, H.; Murata, T.; Usui, T.; Kawagishi, H. Purification, characterization, and sugar binding specificity of an $N$-Glycolylneuraminic acid-specific lectin from the mushroom Chlorophyllum molybdites. J. Biol. Chem. 2004, 279, $53048-53055$.

16. Santhiya, M.; Jan, M. Screening of wild mushroom amanita species for occurrence of lectins and their partial purification by RP-HPLC. Middle East J. Sci. Res. 2013, 14, 456-460.

17. Zhao, J.K.; Wang, H.X.; Ng, T.B. Purification and characterization of a novel lectin from the toxic wild mushroom Inocybe umbrinella. Toxicon 2009, 53, 360-366.

18. Epis, S.; Matinato, C.; Gentili, G.; Varotto, F.; Bandi, C.; Sassera, D. Molecular detection of poisonous mushrooms in different matrices. Mycologia 2010, 102, 747-754.

19. Boa, E. Wild Edible Fungi, a Global Overview of Their Use and Importance to People; Food and Agriculture Organization of the United Nations: Rome, Italy, 2004.

20. Li, Y.R.; Liu, Q.H.; Wang, H.X.; Ng, T.B. A novel lectin with potent antitumor, mitogenic and HIV-1 reverse transcriptase inhibitory activities from the edible mushroom Pleurotus citrinopileatus. Biochim. Biophys. Acta 2008, 1780, 51-57.

21. Pemberton, R.T. Agglutinins (lectins) from some British higher fungi. Mycol. Res. 1994, 98, 277-290.

22. Zhang, Y.; Liu, Z.; Ng, T.B.; Chen, Z.; Qiao, W.; Liu, F. Purification and characterization of a novel antitumor protein with antioxidant and deoxyribonuclease activity from edible mushroom Pholiota nameko. Biochime 2014, 99, 28-37. 
23. Wang, H.X.; Ng, T.B.; Liu, W.K.; Ooi, V.E.; Chang, S.T. Isolation and characterization of two distinct lectins with antiproliferative activity from the cultured mycelium of the edible mushroom Tricholoma mongolicum. Int. J. Pept. Protein Res. 1995, 46, 508-513.

24. Wang, H.X.; Ng, T.B.; Ooi, V.E.; Liu, W.K.; Chang, S.T. Actions of lectins from the mushroom Tricholoma mongolicum on macrophages, splenocytes and life-span in sarcoma-bearing mice. Anticancer Res. 1997, 17, 419-424.

25. She, Q.B.; Ng, T.B.; Liu, W.K. A novel lectin with potent immunomodulatory activity isolated from both fruiting bodies and cultured mycelia of the edible mushroom Volvariella volvacea. Biochem. Biophys. Res. Commun. 1998, 247, 106-111.

26. Wang, H.; Gao, J.; Ng, T.B. A new lectin with highly potent antihepatoma and antisarcoma activities from the Oyster mushroom Pleurotus ostreatus. Biochem. Biophys. Res. Commun. 2000, $275,810-816$.

27. Wang, H.; Ng, T.B.; Liu, Q. Isolation of a new heterodimeric lectin with mitogenic activity from fruiting bodies of the mushroom Agrocybe cylindracea. Life Sci. 2002, 70, 877-885.

28. Yang, N.; Tong, X.; Xiang, Y.; Zhang, Y.; Sun, H.; Wang, D.C. Crystallization and preliminary crystallographic studies of the recombinant antitumour lectin from the edible mushroom Agrocybe aegerita. Biochim. Biophys. Acta 2005, 1751, 209-212.

29. Kawagishi, H.; Mitsunaga, S.; Yamawaki, M.; Ido, M.; Shimada, A.; Kinoshita, T.; Murata, T.; Usui, T.; Kimura, A.; Chiba, S. A lectin from mycelia of the fungus Ganoderma lucidum. Phytochemistry 1997, 44, 7-10.

30. Stepanova, L.V.; Nikitina, V.E.; Borko, A.S. Isolation and characterization of lectin from the surface of Grifola frondosa (Fr.) S.F.Gray mycelium. Mikrobiologiia 2007, 76, 488-493.

31. Zhao, J.K.; Zhao, Y.C.; Li, S.H.; Wang, H.X.; Ng, T.B. Isolation and characterization of a novel thermostable lectin from the wild edible mushroom Agaricus arvensis. J. Basic Microbiol. 2011, 51, 304-311.

32. Yu, L.; Fernig, D.G.; Smith, J.A.; Milton, J.D.; Rhodes, J.M. Reversible inhibition of proliferation of epithelial cell lines by Agaricus bisporus (edible mushroom) lectin. Cancer Res. 1993, 53, 4627-4632.

33. Batterbury, M.; Tebbs, C.A.; Rhodes, J.M.; Grierson, I. Agaricus bisporus (edible mushroom lectin) inhibits ocular fibroblast proliferation and collagen lattice contraction. Exp. Eye Res. 2002, 74, 361-370.

34. Cheung, Y.H.; Sheridan, C.M.; Lo, A.C.; Lai, W.W. Lectin from Agaricus bisporus inhibited S phase cell population and Akt phosphorylation in human RPE cells. Investig. Ophthalmol. Vis. Sci. 2012, 53, 7469-7475.

35. Kawagishi, H.; Nomura, A.; Yumen, T.; Mizuno, T.; Hagiwara, T.; Nakamura, T. Isolation and properties of a lectin from the fruiting bodies of Agaricus blazei. Carbohydr. Res. 1988, 183, $150-154$.

36. Yang, N.; Li, D.F.; Feng, L.; Xiang, Y.; Liu, W.; Sun, H.; Wang, D.C. Structural basis for the tumor cell apoptosis-inducing activity of an antitumor lectin from the edible mushroom Agrocybe aegerita. J. Mol. Biol. 2009, 387, 694-705.

37. Sun, H.; Zhao, C.G.; Tong, X.; Qi, Y.P. A lectin with mycelia differentiation and antiphytovirus activities from the edible mushroom Agrocybe aegerita. J. Biochem. Mol. Biol. 2003, 36, 214-222. 
38. Zhao, C.; Sun, H.; Tong, X.; Qi, Y. An antitumour lectin from the edible mushroom Agrocybe aegerita. Biochem. J. 2003, 374, 321-327.

39. Ren, X.; Jiang, S.; Li, D.; Sun, H.; Wang, D. Crystallization and preliminary crystallographic studies of AAL-2, a novel lectin from Agrocybe aegerita that binds nonreducing terminal $N$-acetylglucosamine. Acta Crystallogr. Sect. F Struct. Biol. Cryst. Commun. 2013, 69, 650-652.

40. Jiang, S.; Chen, Y.; Wang, M.; Yin, Y.; Pan, Y.; Gu, B.; Yu, G.; Li, Y.; Wong, B.H.; Liang, Y.; et al. A novel lectin from Agrocybe aegerita shows high binding selectivity for terminal $N$-acetylglucosamine. Biochem. J. 2012, 443, 369-378.

41. Yagi, F.; Miyamoto, M.; Abe, T.; Minami, Y.; Tadera, K.; Goldstein, I.J. Purification and carbohydrate-binding specificity of Agrocybe cylindracea lectin. Glycoconj. J. 1997, 14, 281-288.

42. Hu, D.; Tateno, H.; Sato, T.; Narimatsu, H.; Hirabayashi, J. Tailoring GalNAc $\alpha 1-3 G a 1 \beta$-specific lectins from a multi-specific fungal galectin: Dramatic change of carbohydrate specificity by a single amino-acid substitution. Biochem. J. 2013, 453, 261-270.

43. Olausson, J.; Tibell, L.; Jonsson, B.H.; Påhlsson, P. Detection of a high affinity binding site in recombinant Aleuria aurantia lectin. Glycoconj. J. 2008, 25, 753-762.

44. Kochibe, N.; Furukawa, K. Purification and properties of a novel fucosespecific hemagglutinin of Aleuria aurantia. Biochemistry 1980, 19, 2841-2846.

45. Yagi, F.; Tadera, K. Purification and characterization of lectin from Auricularia polytricha. Agric. Biol. Chem. 1988, 52, 2077-2079.

46. Koyama, Y.; Katsuno, Y.; Miyoshi, N.; Hayakawa, S.; Mita, T.; Muto, H.; Isemura, S.; Aoyagi, Y.; Isemura, M. Apoptosis induction by lectin isolated from the mushroom Boletopsis leucomelas in U937 cells. Biosci. Biotechnol. Biochem. 2002, 66, 784-789.

47. Zheng, S.; Li, C.; Ng, T.B.; Wang, H.X. A lectin with mitogenic activity from the edible wild mushroom Boletus edulis. Process Biochem. 2007, 42, 1620-1624.

48. Bovi, M.; Carrizo, M.E.; Capaldi, S.; Perduca, M.; Chiarelli, L.R.; Galliano, M.; Monaco, H.L. Structure of a lectin with antitumoral properties in king bolete (Boletus edulis) mushrooms. Glycobiology 2011, 21, 1000-1009.

49. Bovi, M.; Cenci, L.; Perduca, M.; Capaldi, S.; Carrizo, M.E.; Civiero, L.; Chiarelli, L.R.; Galliano, M.; Monaco, H.L. BEL $\beta$-trefoil: A novel lectin with antineoplastic properties in king bolete (Boletus edulis) mushrooms. Glycobiology 2013, 23, 578-592.

50. Lyimo, B.; Funakuma, N.; Minami, Y.; Yagi, F. Characterization of a new $\alpha$-galactosyl-binding lectin from the mushroom Clavaria purpurea. Biosci. Biotechnol. Biochem. 2012, 76, 336-342.

51. Svajger, U.; Pohleven, J.; Kos, J.; Strukelj, B.; Jeras, M. CNL, a ricin B-like lectin from mushroom Clitocybe nebularis, induces maturation and activation of dendritic cells via the toll-like receptor 4 pathway. Immunology 2011, 134, 409-418.

52. Pohleven, J.; Brzin, J.; Vrabec, L.; Leonardi, A.; Cokl, A.; Strukelj, B.; Kos, J.; Sabotič, J. Basidiomycete Clitocybe nebularis is rich in lectins with insecticidal activities. Appl. Microbiol. Biotechnol. 2011, 91, 1141-1148.

53. Pohleven, J.; Renko, M.; Magister, Š.; Smith, D.F.; Künzler, M.; Štrukelj, B.; Turk, D.; Kos, J.; Sabotič, J. Bivalent carbohydrate binding is required for biological activity of Clitocybe nebularis lectin (CNL), the $N, N^{\prime}$-diacetyllactosediamine (GalNAc $\beta 1-4 \mathrm{GlcNAc}$, LacdiNAc)-specific lectin from basidiomycete C. nebularis. J. Biol. Chem. 2012, 287, 10602-10612. 
54. Walti, M.A.; Walser, P.J.; Thore, S.; Grunler, A.; Bednar, M.; Kunzler, M.; Aebi, M. Structural basis for chitotetraose coordination by CGL3, a novel galectin-related protein from Coprinopsis cinerea. J. Mol. Biol. 2008, 379, 146-159.

55. Yatohgo, T.; Nakata, M.; Tsumuraya, Y.; Hashimoto, Y.; Yamamoto, S. Purification and properties of a lectin from the fruitbodies of Flammulina velutipes. Agric. Biol. Chem. 1988, 52, $1485-1493$.

56. Ng, T.B.; Ngai, P.H.; Xia, L. An agglutinin with mitogenic and antiproliferative activities from the mushroom Flammulina velutipes. Mycologia 2006, 98, 167-171.

57. Ngai, P.H.; Ng, T.B. A mushroom (Ganoderma capense) lectin with spectacular thermostability, potent mitogenic activity on splenocytes, and antiproliferative activity toward tumor cells. Biochem. Biophys. Res. Commun. 2004, 314, 988-993.

58. Kawagishi, H.; Nomura, A.; Mizuno, T.; Kimura, A.; Chiba, S. Isolation and characterization of a lectin from Grifola frondosa fruiting bodies. Biochim. Biophys. Acta 1990, 1034, 247-252.

59. Alborés, S.; Mora, P.; Bustamante, M.J.; Cerdeiras, M.P.; Franco Fraguas, L. Purification and applications of a lectin from the mushroom Gymnopilus spectabilis. Appl. Biochem. Biotechnol. 2014, 172, 2081-2090.

60. Kawagishi, H.; Mori, H.; Unoa, A.; Kimurab, A.; Chibab, S. A sialic acid-binding lectin from the mushroom Hericium erinaceum. FEBS Lett. 1994, 340, 56-58.

61. Suzuki, T.; Sugiyama, K.; Hirai, H.; Ito, H.; Morita, T.; Dohra, H.; Murata, T.; Usui, T.; Tateno, H.; Hirabayashi, J.; et al. Mannose-specific lectin from the mushroom Hygrophorus russula. Glycobiology 2012, 22, 616-629.

62. Guillot, J.; Gernaud, L.; Gueugnot, I.; Damez, M. Purification and properties of two hemagglutinins of the mushroom Laccaria amethystina. Biochemistry 1983, 22, 5365-5369.

63. Lyimo, B.; Yagi, F.; Minami, Y. Primary structure and specificity of a new member of galectin family from the Amethyst deceiver mushroom Laccaria amethystina. Biosci. Biotechnol. Biochem. 2011, 75, 62-69.

64. Wohlschlager, T.; Butschi, A.; Grassi, P.; Sutov, G.; Gauss, R.; Hauck, D.; Schmieder, S.S.; Knobel, M.; Titz, A.; Dell, A.; et al. Methylated glycans as conserved targets of animal and fungal innate defense. Proc. Natl. Acad. Sci. USA 2014, 111, E2787-E2796.

65. Guillot, J.; Giollant, M.; Damez, M.; Dusser, M. Isolation and characterization of a lectin from the mushroom, Lactarius deliciosus. J. Biochem. 1991, 109, 840-845.

66. Giollant, M.; Guillot, J.; Damez, M.; Dusser, M.; Didier, P.; Didier, E. Characterization of a Lectin from Lactarius deterrimus (Research on the Possible Involvement of the Fungal Lectin in Recognition between Mushroom and Spruce during the Early Stages of Mycorrhizae Formation). Plant Physiol. 1993, 101, 513-522.

67. Wu, Y.; Wang, H.; Ng, T.B. Purification and characterization of a lectin with antiproliferative activity toward cancer cells from the dried fruit bodies of Lactarius flavidulus. Carbohydr. Res. 2011, 346, 2576-2581.

68. Panchak, L.V.; Antoniuk, V.O. Purification of lectin from fruiting bodies of Lactarius rufus (Scop.: Fr.)Fr. and its carbohydrate specificity. Ukr. Biokhim. Zh. 2007, 79, 123-128. 
69. Konska, G.; Guillot, J.; Dusser, M.; Damez, M.; Botton, B. Isolation and characterization of an $\mathrm{N}$-acetyllactosamine-binding lectin from the mushroom Laetiporus sulfureus. J. Biochem. 1994, $116,519-523$.

70. Mancheño, J.M.; Tateno, H.; Goldstein, I.J.; Martínez-Ripoll, M.; Hermoso, J.A. Structural analysis of the Laetiporus sulphureus hemolytic pore-forming lectin in complex with sugars. J. Biol. Chem. 2005, 280, 17251-17259.

71. Tateno, H.; Goldstein, I.J. Molecular cloning, expression, and characterization of novel hemolytic lectins from the mushroom Laetiporus sulphureus, which show homology to bacterial toxins. J. Biol. Chem. 2003, 278, 40455-40463.

72. Wang, H.X.; Ng, T.B.; Ooi, V.E.C. Studies on purification of a lectin from fruiting bodies of the edible shiitake mushroom Lentinus edodes. Int. J. Biochem. Cell Biol. 1999, 31, 595-599.

73. Moon, I.J.; Chung, S.R.; Jeune, K.H. Mitotic stimulation and cancer cell agglutination of the lectin from Lentinus edodes. Yakhak Hoeji 1995, 39, 260-267. (In Korean)

74. Goldstein, I.J.; Winter, H.C.; Aurandt, J.; Confer, L.; Adamson, J.T.; Hakansson, K.; Remmer, H. A new alpha-galactosyl-binding protein from the mushroom Lyophyllum decastes. Arch. Biochem. Biophys. 2007, 467, 268-274.

75. Ng, T.B.; Lam, Y.W. Isolation of a novel agglutinin with complex carbohydrate binding specificity from fresh fruiting bodies of the edible mushroom Lyophyllum shimeiji. Biochem. Biophys. Res. Commun. 2002, 290, 563-568.

76. Žurga, S.; Pohleven, J.; Renko, M.; Bleuler-Martinez, S.; Sosnowski, P.; Turk, D.; Künzler, M.; Kos, J.; Sabotič, J. A novel $\beta$-trefoil lectin from the parasol mushroom (Macrolepiota procera) is nematotoxic. FEBS J. 2014, 281, 3489-3506.

77. Winter, H.C.; Mostafapour, K.; Goldstein, I.J. The mushroom Marasmius oreades lectin is a blood group type B agglutinin that recognizes the Galalpha 1,3Gal and Galalpha 1,3Galbeta 1,4GlcNAc porcine xenotransplantation epitopes with high affinity. J. Biol. Chem. 2002, 277, 14996-15001.

78. Cordara, G.; Egge-Jacobsen, W.; Johansen, H.T.; Winter, H.C.; Goldstein, I.J.; Sandvig, K.; Krengel, U. Marasmius oreades agglutinin (MOA) is a chimerolectin with proteolytic activity. Biochem. Biophys. Res. Commun. 2011, 408, 405-410.

79. Cordara, G.; Winter, H.C.; Goldstein, I.J.; Krengel, U.; Sandvig, K. The fungal chimerolectin MOA inhibits protein and DNA synthesis in NIH/3T3 cells and may induce BAX-mediated apoptosis. Biochem. Biophys. Res. Commun. 2014, 447, 586-589.

80. Shimokawa, M.; Fukudome, A.; Yamashita, R.; Minami, Y.; Yagi, F.; Tateno, H.; Hirabayashi, J. Characterization and cloning of GNA-like lectin from the mushroom Marasmius oreades. Glycoconj. J. 2012, 29, 457-465.

81. Kawagishi, H.; Takagi, J.; Taira, T.; Murata, T.; Usui, T. Purification and characterization of a lectin from the mushroom Mycoleptodonoides aitchisonii. Phytochemistry 2001, 56, 53-58.

82. Zhang, G.Q.; Sun, J.; Wang, H.X.; Ng, T.B. A novel lectin with antiproliferative activity from the medicinal mushroom Pholiota adiposa. Acta Biochim. Pol. 2009, 56, 415-421.

83. Kobayashi, Y.; Tateno, H.; Dohra, H.; Moriwaki, K.; Miyoshi, E.; Hirabayashi, J.; Kawagishi, H. A novel core fucose-specific lectin from the mushroom Pholiota squarrosa. J. Biol. Chem. 2012, 287, 33973-33982. 
84. Suzuki, T.; Amano, Y.; Fujita, M.; Kobayashi, Y.; Dohra, H.; Hirai, H.; Murata, T.; Usui, T.; Morita, T.; Kawagishi, H. Purification, characterization, and cDNA cloning of a lectin from the mushroom Pleurocybella porrigens. Biosci. Biotechnol. Biochem. 2009, 73, 702-709.

85. Xu, C.J.; Wang, Y.X.; Niu, B.N.; Liu, B.; Li, Y.B.; Wang, X.M.; Lu, S.L. Isolation and characterization of a novel lectin with mitogenic activity from Pleurotus ferulae. Pak. J. Pharm. Sci. 2014, 27, 983-989.

86. Gao, W.; Sun, Y.; Chen, S.; Zhang, J.; Kang, J.; Wang, Y.; Wang, H.; Xia, G.; Liu, Q.; Kang, Y. Mushroom lectin enhanced immunogenicity of HBV DNA vaccine in C57BL/6 and HBsAg-transgenic mice. Vaccine 2013, 31, 2273-2280.

87. Jedinak, A.; Dudhgaonkar, S.; Wu, Q.L.; Simon, J.; Sliva, D. Anti-inflammatory activity of edible

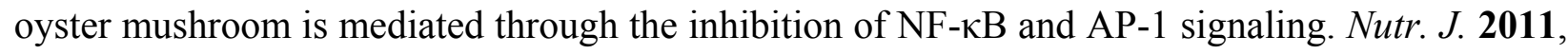
10, 52. Available online: http://www.biomedcentral.com/content/pdf/1475-2891-10-52.pdf (accessed on 24 December 2014).

88. Wang, H.; $\mathrm{Ng}$, T.B. Isolation of a novel $\mathrm{N}$-acetylglucosamine-specific lectin from fresh sclerotia of the edible mushroom Pleurotus tuber-regium. Protein Expr. Purif. 2003, 29, 156-160.

89. Wang, H.; Ng, T.B.; Liu, Q. A novel lectin from the wild mushroom Polyporus adusta. Biochem. Biophys. Res. Commun. 2003, 307, 535-539.

90. Mo, H.; Winter, H.C.; Goldstein, I.J. Purification and characterization of a Neu5Acalpha2-6Galbeta1-4Glc/GlcNAc-specific lectin from the fruiting body of the polypore mushroom Polyporus squamosus. J. Biol. Chem. 2000, 275, 10623-10629.

91. Cioci, G.; Mitchell, E.P.; Chazalet, V.; Debray, H.; Oscarson, S.; Lahmann, M.; Gautier, C.; Breton, C.; Perez, S.; Imberty, A. $\beta$-propeller crystal structure of Psathyrella velutina lectin: An integrin-like fungal protein interacting with monosaccharides and calcium. J. Mol. Biol. 2006, 357, 1575-1591.

92. Kochibe, N.; Matta, K.L. Purification and properties of an $N$-acetylglucosamine-specific lectin from Psathyrella velutina mushroom. J. Biol. Chem. 1989, 264, 173-177.

93. Zhao, S.; Zhao, Y.; Li, S.; Zhao, J.; Zhang, G.; Wang, H.; Ng, T.B. A novel lectin with highly potent antiproliferative and HIV-1 reverse transcriptase inhibitory activities from the edible wild mushroom Russula delica. Glycoconj. J. 2010, 27, 259-265.

94. Han, C.H.; Liu, Q.H.; Ng, T.B.; Wang, H.X. A novel homodimeric lactose-binding lectin from the edible split gill medicinal mushroom Schizophyllum commune. Biochem. Biophys. Res. Commun. 2005, 336, 252-257.

95. Zhang, W.; Tian, G.; Geng, X.; Zhao, Y.; Ng, T.B.; Zhao, L.; Wang, H. Isolation and Characterization of a Novel Lectin from the Edible Mushroom Stropharia rugosoannulata. Molecules 2014, 19, 19880-19891.

96. Trigueros, V.; Lougarre, A.; Ali-Ahmed, D.; Rahbé, Y.; Guillot, J.; Chavant, L.; Fournier, D.; Paquereau, L. Xerocomus chrysenteron lectin: Identification of a new pesticidal protein. Biochim. Biophys. Acta 2003, 1621, 292-298.

97. Liu, Q.; Wang, H.; Ng, T.B. Isolation and characterization of a novel lectin from the wild mushroom Xerocomus spadiceus. Peptides 2004, 25, 7-10. 
98. Liu, Q.; Wang, H.; Ng, T.B. First report of a xylose-specific lectin with potent hemagglutinating, antiproliferative and anti-mitogenic activities from a wild ascomycete mushroom. Biochim. Biophys. Acta 2006, 1760, 1914-1919.

99. Wang, H.X.; Ooi, V.E.; Ng, T.B.; Chiu, K.W.; Chang, S.T. Hypotensive and vasorelaxing activities of a lectin from the edible mushroom Tricholoma mongolicum. Pharmacol. Toxicol. 1996, 79, 318-323.

100. Fukumori, F.; Takeuchi, N.; Hagiwara, T.; Ohbayashi, H.; Endo, T.; Kochibe, N.; Nagata, Y.; Kobata, A. Primary structure of a fucose-specific lectin obtained from a mushroom, Aleuria aurantia. J. Biochem. 1990, 107, 190-196.

101. Crenshaw, R.W.; Harper, S.N.; Moyer, M.; Privalle, L.S. Isolation and characterization of a cDNA clone encoding a lectin gene from Agaricus bisporus. Plant Physiol. 1995, 107, 1465-1466.

102. Ko, J.L.; Hsu, C.I.; Lin, R.H.; Kao, C.L.; Lin, J.Y. A new fungal immunomodulatory protein, FIP-five isolated from the edible mushroom, Flammulina velutipes and its complete amino acid sequence. Eur. J. Biochem. 1995, 228, 244-249.

103. Li, Y.; Zhang, G.; Ng, T.B.; Wang, H. A novel lectin with antiproliferative and HIV-1 reverse transcriptase inhibitory activities from dried fruiting bodies of the monkey head mushroom Hericium erinaceum. J. Biomed. Biotechnol. 2010, 2010, 716515, doi:10.1155/2010/716515.

104. Martin, F.; Aerts, A.; Ahren, D.; Brun, A.; Danchin, E.G.; Duchaussoy, F.; Gibon, J.; Kohler, A. The genome of Laccaria bicolor provides insights into mycorrhizal symbiosis. Nature 2008, 452, 42-43.

105. Kruger, R.P.; Winter, H.C.; Simonson-Leff, N.; Stuckey, J.A.; Goldstein, I.J.; Dixon, J.E. Cloning, expression, and characterization of the Galalpha 1,3Gal high affinity lectin from the mushroom Marasmius oreades. J. Biol. Chem. 2002, 277, 15002-15005.

106. Wang, S.X.; Zhang, G.Q.; Zhao, S.; Xu, F.; Zhou, Y.; Li Geng, X.; Liu, Y.; Wang, H.X. Purification and characterization of a novel lectin with antiphytovirus activities from the wild mushroom Paxillus involutus. Protein Pept. Lett. 2013, 20, 767-774.

107. Kawagishi, H.; Abe, Y.; Nagata, T.; Kimura, A.; Chiba, S. A lectin from the mushroom Pholiota aurivella. Agric. Biol. Chem. 1991, 55, 2485-2489.

108. Oguri, S.; Ando, A.; Nagata, Y. A novel developmental stage-specific lectin of the basidiomycete Pleurotus cornucopiae. J. Bacteriol. 1996, 178, 5692-5698.

109. Devi, K.S.; Roy, B.; Patra, P.; Sahoo, B.; Islam, S.S.; Maiti, T.K. Characterization and lectin microarray of an immunomodulatory heteroglucan from Pleurotus ostreatus mycelia. Carbohydr. Polym. 2013, 94, 857-865.

110. Guillot, J.; Konska, G. Lectins in higher fungi. Biochem. Syst. Ecol. 1997, 25, 203-230.

111. Khan, F.; Khan, M.I. Fungal Lectins: Current molecular and biochemical perspectives. Int. J. Biol. Chem. 2011, 5, 1-20.

112. Lin, J.Y.; Chou, T.B. Isolation and characterization of a lectin from edible mushroom, Volvariella volvacea. J. Biochem. 1984, 96, 35-40.

113. Yang, N.; Tong, X.; Xiang, Y.; Zhang, Y.; Liang, Y.; Sun, H.; Wang, D.C. Molecular character of the recombinant antitumor lectin from the edible mushroom Agrocybe aegerita. J. Biochem. 2005, $138,145-150$. 
114. Lin, W.H.; Hung, C.H.; Hsu, C.I.; Lin, J.Y. Dimerization of the N-terminal amphipathic alpha-helix domain of the fungal immunomodulatory protein from Ganoderma tsugae (Fip-gts) defined by a yeast two-hybrid system and site-directed mutagenesis. J. Biol. Chem. 1997, 272, 20044-20048.

115. Bastiaan-Net, S.; Chanput, W.; Hertz, A.; Zwittink, R.D.; Mes, J.J.; Wichers, H.J. Biochemical and functional characterization of recombinant fungal immunomodulatory proteins (rFIPs). Int. Immunopharmacol. 2013, 15, 167-175.

116. Wasser, S.P. Medicinal mushroom science: Current perspectives, advances, evidences, and challenges. Biomed. J. 2014, 37, 345-356.

(C) 2014 by the authors; licensee MDPI, Basel, Switzerland. This article is an open access article distributed under the terms and conditions of the Creative Commons Attribution license (http://creativecommons.org/licenses/by/4.0/). 